\title{
SOCIAL AND ENVIRONMENTAL FACTORS IN CHRONIC BRONCHITIS IN NEWCASTLE UPON TYNE
}

\author{
A. G. Ogilvie, M.D., F.R.C.P. \\ Royal Victoria Infirmary, Newcastle upon Tyne
}

The study of social habits and conditions, and of environment in relation to disease, is timeconsuming, and progress is slow.

Despite much work, a great deal remains to be learned regarding the natural history of chronic bronchitis, and the effect upon it of the conditions of life and work. The greater part of the work in this field has been carried out from the Pneumoconiosis Research Unit of the Medical Research Council in South Wales, from the University of Sheffield, and from the Postgraduate Medical School of London.

This work will be referred to in the following discussion, but the main intention is to consider the disease as it affects Newcastle, and in the light of information gleaned in a survey of the city which was carried out in $1955-56 .^{12}$ At that time the basic problem of the clinical recognition of the disease had hardly been considered, much less solved, and it will readily be appreciated that in any such survey diagnosis is crucial.

The advanced case may readily be recognized, but the main object of such environmental study is lost unless all cases, the early and mild, as well as the advanced, are included. Symptoms are all we have in the early stage of bronchitis, and the disease is usually gradual in onset. Nevertheless, a point must be recognized at which we are to say that the disease exists-and the following definition was set up. ' . . . chronic bronchitis is recognized as a long-standing condition, the essential features of which are cough with sputum, persistent throughout the winter or throughout the year, in the absence of other causative respiratory disease. A minimum duration of two years is essential for its recognition'. The diagnosis of chronic bronchitis during the Newcastle survey was based on this definition. It has been criticized, but has lately received support from the careful, intensive and ingenious work of Fletcher and his colleagues at the Postgraduate Medical School. ${ }^{3}$
They conclude that there is an early phase of hypersecretion of mucus which precedes the later infective stage. This fits well with the pathological studies of Lynne Reid, ${ }^{19}$ who showed that mucous hypertrophy was an essential feature of the disease.

Goodman, Lane and Rampling ${ }^{5}$ emphasized the high mortality in the urban and industrial regions of England and Wales, which they found to be two or three times that of the rural districts.

Table 1.-Bronchitis Deaths 1954: Rates PER I0,000 PER YEAR

\begin{tabular}{|c|c|c|c|c|}
\hline Area & Age & $45-64$ & Age & $65-74$ \\
\hline $\begin{array}{l}\text { Tyneside conurbation } \\
\text { S.E. Lancs. } \\
\text { S. Western region }\end{array}$ & $\begin{array}{l}\text { M. } \\
10.9 \\
17.1 \\
5.9\end{array}$ & $\begin{array}{l}\text { F. } \\
1.9 \\
4.6 \\
1.0\end{array}$ & $\begin{array}{l}\text { M. } \\
38.8 \\
76.8 \\
30.2\end{array}$ & $\begin{array}{r}\text { F. } \\
16.7 \\
24.1 \\
6.5\end{array}$ \\
\hline England and Wales & 9.8 & 2.0 & $43 \cdot 5$ & II.3 \\
\hline
\end{tabular}

This work was published at about the same time as that of Oswald, ${ }^{14}$ Lynne Reid, 18, 19 and May ${ }^{10}$ from the Brompton Hospital, so that both the challenge and the knowledge essential to meet it appeared together.

Goodman et al. underlined the association of death from bronchitis in both sexes with 'urbani-

Table 2.-Bronchitis Death Rates Per 10,000 (AGE 45-54), I950

(Modified from Goodman, Lane \& Rampling)

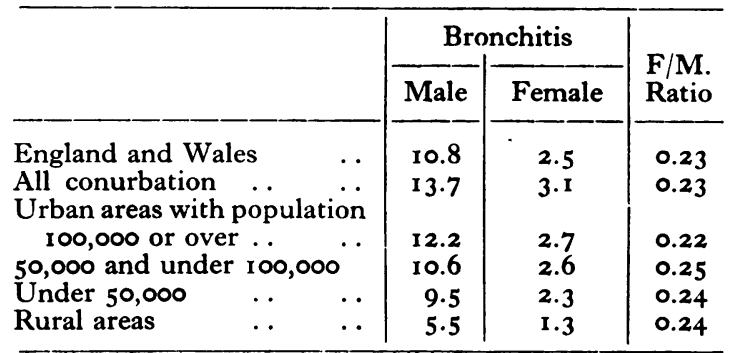


zation', and showed a progressive decline in mortality in relation to the size of towns.

The term 'conurbation' is extremely ugly, nearly as ugly as some of the 'conurbations' themselves, but seems to have come to stay. Its meaning may easily be guessed. The ratio of female to male deaths is given in the form of a quotient, and it will be noticed that it is quite unaffected by the size of the town. Both sexes are affected equally by this, it would seem, and some other factor or factors must be involved in this difference between the sexes.

The air over our large towns is known to contain sulphur compounds, and these are known to affect ciliary activity and mucous function in animals, and there is some evidence that they can do so in man, although there seems to be much variation in experimental work. ${ }^{1,8}$

Stocks studied the relationship between hours of sunshine and bronchitis deaths. He found that the less the hours of sunshine the higher the death rate from bronchitis. Not only is sunshine beneficial to health, but it causes polluting substances tc rise above breathing level. The position in Newcastle may be assessed from the fact that the Medical School, which is not in the 'dirty' part of the city, receives 900 hours of sunshine per annum, as compared with Bournemouth's 1,700 .

Pemberton and Goldberg ${ }^{16}$ compared sulphur dioxide pollution in 35 county boroughs, and showed a direct relationship to mortality from bronchitis. Atmospheric pollution by chemical poisons is associated with soot and solid particles, and may be assumed to be present in very sooty 'dirty' localities.

A number of authors have shown a relationship between cigarette smoking and bronchitis. Doll and $\mathrm{Hill}^{2}$ showed a rising mortality rate with rising consumption, and Higgins ${ }^{7}$ a demonstrated an increase in respiratory symptoms, and a decrease in respiratory function in cigarette smokers. Oswald and Medvei noted a similar association. ${ }^{15}$

When a survey of the city of Newcastle was planned, the above environmental and social factors were uppermost in our minds, though constitutional and infective influences were also considered as probably important. Stuart-Harris ${ }^{24}$ stated that 'there is no doubt that . . . attacks of acute bronchitis occur during the early life of individuals, who later become crippled from chronic bronchitis'. In connection with this view, overcrowding was an obvious target.

The attempt to study these features was made, although the difficulties inherent in a retrospective inquiry were appreciated.

In the social and environmental study of a longcontinued disease such as chronic bronchitis, a great difficulty is to estimate the predominant environment, and the social and other influences $\frac{2}{3}$ over long periods of time. People move about, they change their jobs, and sometimes even their $\stackrel{\varrho}{c}$ habits, and memories may play tricks.

This difficulty was met, as far as possible, by $\stackrel{\overline{\vec{S}}}{\rightarrow}$ concentrating on conditions of housing and 0 occupation, rather than upon actual houses and $\frac{\partial}{}$ actual jobs, although these were also recorded. $\frac{\bar{s}}{\frac{1}{2}}$ For example, if a person had lived in apparently $\stackrel{\mathbb{\Omega}}{\Omega}$ 'clean' areas of the city for most of his life, this was regarded as the important thing, no matter how many houses he had lived in. Occupational conditions were similarly classified.

The city of Newcastle lies along the winding river, which is narrow with steep banks. Most of $\overrightarrow{0}$ the inhabitants still live within a mile of the river 3 . bank. Rehousing has been actively pursued, but for local reasons a great many of the houses are just as close to the river as their predecessors. The main $\overrightarrow{\vec{A}}$ source of pollution, the trains and industrial undertakings, are concentrated along the river (although $\stackrel{\circ}{\rightarrow}$ the diesel trains now running will no doubt reduce 은 the total significantly) and the topography just described is that generally considered to favour $\frac{D}{0}$ pollution. The domestic grate, also an important contaminator of the air, is more widespread, but, $\vec{\theta}$ as will be shown later, it, too, is mainly co\& 8 centrated within a mile of the river.

This state of affairs gave rise to an expectatiog that pollution may vary in different parts of the city, particularly as the inhabitants are confident in distinguishing between 'clean' and 'dirty' $\frac{\varnothing}{\varnothing}$ areas, these terms, of course, being in reality $\varrho$ relative only.

It was therefore possible to classify a locality as 'clear' or as sooty and liable to damp and fog ('not clear'), and a further classification of locality into 'enclosed' and 'open' was made. The newero housing is much better spaced than the old. The dwellings stand farther apart, and there are spaces $\frac{3}{3}$ between them, in contradistinction to the older. type of planning, where they are crowded close $\frac{O}{3}$ together with fewer openings. The air is much more likely to stagnate in this older arrangement, $\frac{}{-}$ and pollution, when present, is thus more liable to persist.

The photographs show the two types of locality quite clearly and also that they can be readily distinguished.

Fig. I shows the city divided by a line one $\omega$ mile from the river, into a riverside and a northern? portion, the riverside being bisected into an eastern and a western area. The figures show that density of housing and bronchitis go together and ${ }^{+}$ that, though there is a relationship between the disease and population, it is much less. In other words, it is overcrowding of houses, rather than $\frac{\mathbb{\Phi}}{\sigma}$ 


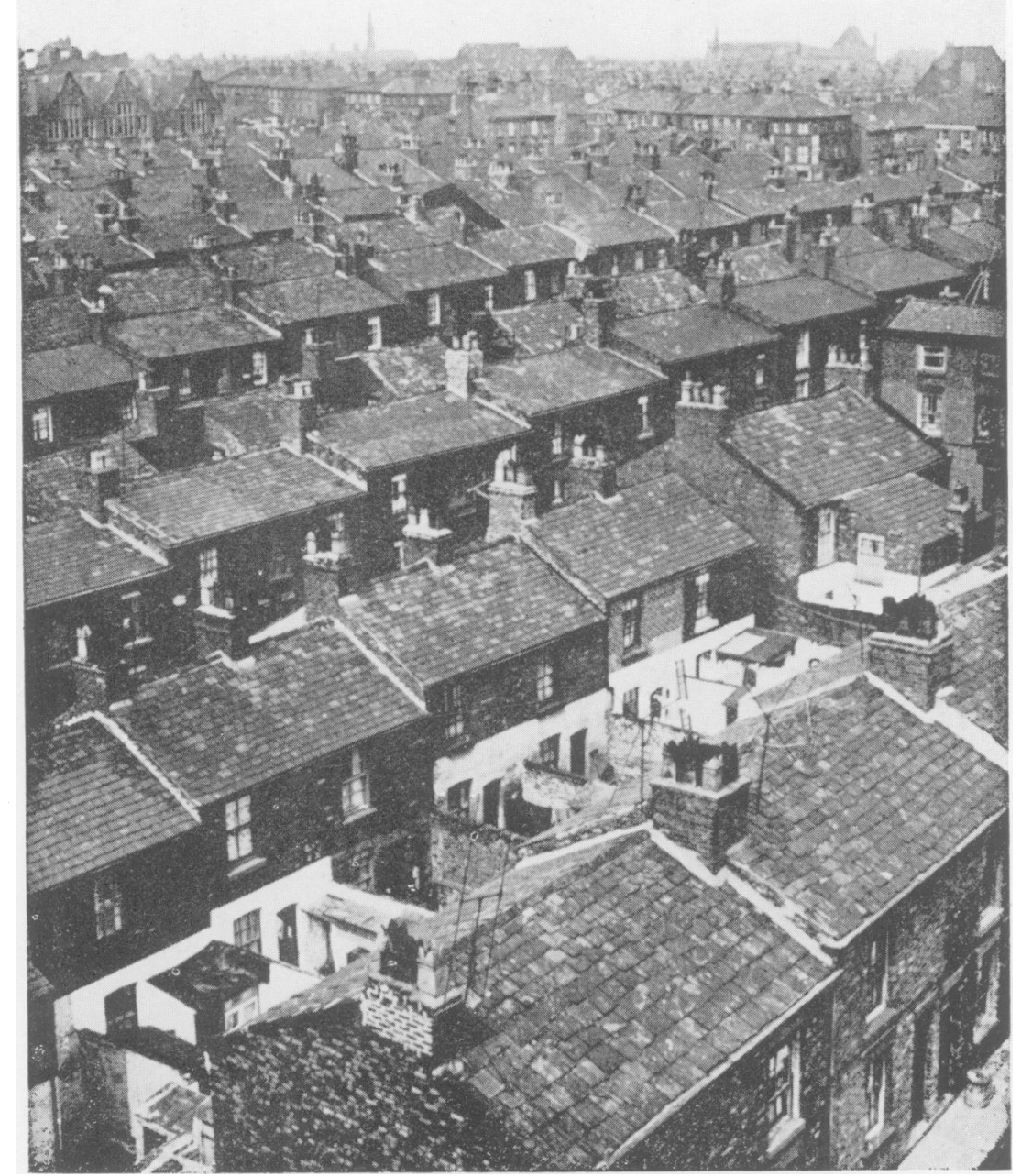

Showing ' enclosed' type of locality.

(By kind permission of 'The Guardian.')

TABLE 3

\begin{tabular}{|c|c|c|c|c|}
\hline \multicolumn{2}{|c|}{ Locality } & Bronchitis & Controls & Totals \\
\hline Enclosed & $\cdots$ & $249(67 \%)$ & $220 \quad(54 \%)$ & 469 \\
\hline Open & $\cdots$ & $121 \quad(33 \%)$ & $190 \quad(46 \%)$ & 3 II \\
\hline Totals & & $370(100 \%)$ & $410(100 \%)$ & 780 \\
\hline
\end{tabular}

overcrowding of people, that is associated with bronchitis.

The association of the 'enclosed' locality with the disease, which is shown in Table 3 , is not unexpected when one looks again at the map.

But is this association perhaps more apparent than real? Atmospheric pollution is likely, from what has been said, to be more intense in the riverside areas and might perhaps of itself account for the result.

That pollution is very likely to be more intense at the river level and within $300 \mathrm{ft}$. of sea level is shown by Fig. 2, which is based on figures for Gateshead, kindly given me by Dr. Grant.

Gateshead is directly opposite Newcastle, over the river, and has a similar topography. It is at $300 \mathrm{ft}$. above sea level that the city of Newcastle 'flattens out' and extends towards its northern boundary, and the 'dirty' locality is less commonly noted. Table 4 shows that the 'dirty' or ' not clear' districts have a significant association with the disease, but on further analysis it was 
Bronchitis 23\%

Population 22 peracre

Dwellings 7.6 per ocre

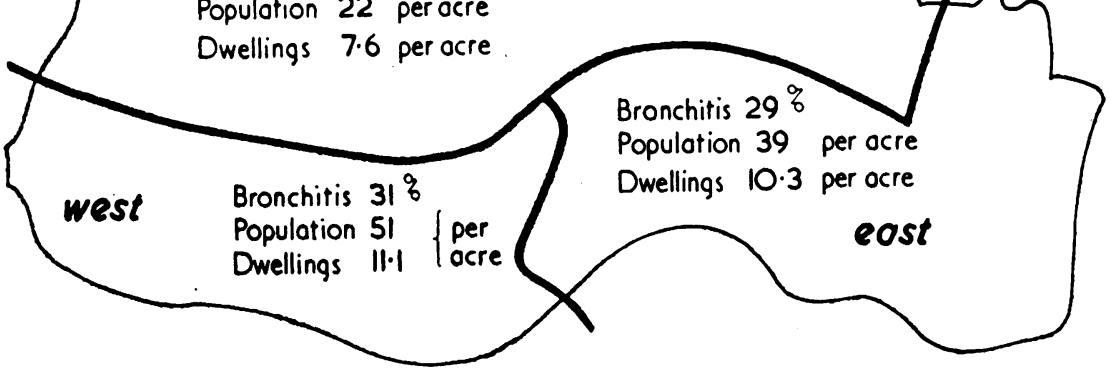

FIG. I

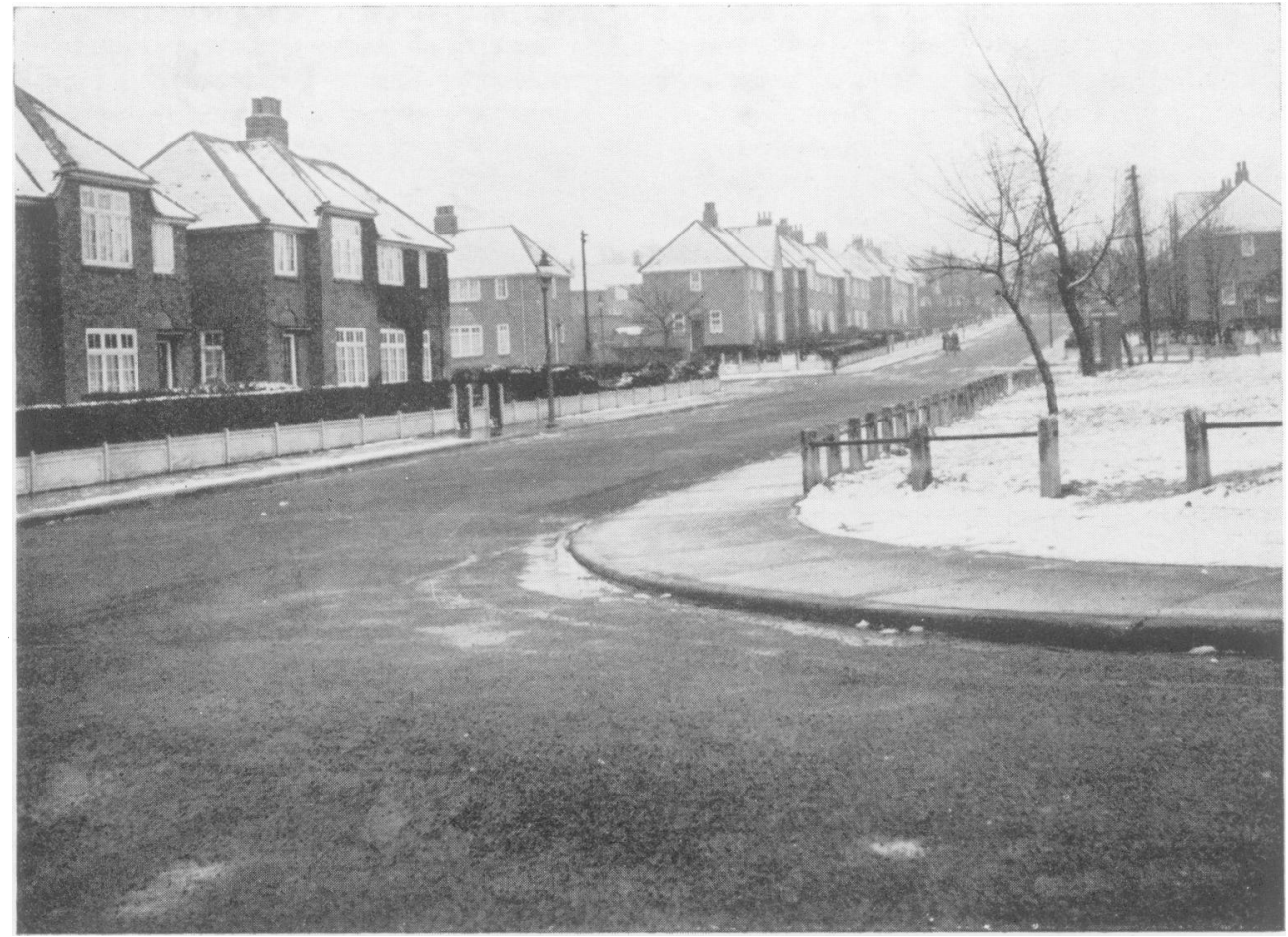


TABLE $\cdot 4$

\begin{tabular}{|c|c|c|c|c|c|c|c|}
\hline \multirow{2}{*}{\multicolumn{2}{|c|}{ Locality }} & \multicolumn{2}{|c|}{ Males } & \multicolumn{2}{|c|}{ Females } & \multicolumn{2}{|c|}{ Totals } \\
\hline & & Ch. Br. & Controls & Ch. Br. & Controls & Br. & Controls \\
\hline \multirow[t]{2}{*}{$\begin{array}{l}\text { 'Clear', } \\
\text { 'Dirty' }\end{array}$} & $\begin{array}{l}. \\
.\end{array}$ & $\begin{array}{r}78 \\
194\end{array}$ & $\begin{array}{r}94 \\
135\end{array}$ & $\begin{array}{r}67 \\
125\end{array}$ & $\begin{array}{r}102 \\
95\end{array}$ & $\begin{array}{ll}145 & (33 \%) \\
329 & (67 \%)\end{array}$ & $\begin{array}{ll}196 & (46 \%) \\
230 & (54 \%)\end{array}$ \\
\hline & & 272 & 229 & 192 & 197 & 474 & 426 \\
\hline
\end{tabular}

Table 5.-Early Acute Respiratory Episodes

\begin{tabular}{|c|c|c|c|c|c|c|c|c|c|c|}
\hline & & & \multicolumn{4}{|c|}{ Males } & \multicolumn{4}{|c|}{ Females } \\
\hline & & & \multicolumn{2}{|c|}{ Bronchitics } & \multicolumn{2}{|c|}{ Controls } & \multicolumn{2}{|c|}{ Bronchitics } & \multicolumn{2}{|c|}{ Controls } \\
\hline & & & No. & $\%$ & No. & $\%$ & No. & $\%$ & No. & $\%$ \\
\hline $\begin{array}{l}\text { Recurrent early episodes } \ldots \\
\text { Infrequent early episodes }\end{array}$ & $\begin{array}{l}\cdots \\
\cdots\end{array}$ & $\begin{array}{l}. \\
. \\
\end{array}$ & $\begin{array}{r}43 \\
229\end{array}$ & $\begin{array}{l}16 \\
84\end{array}$ & $\begin{array}{r}15 \\
224\end{array}$ & $\begin{array}{r}6 \\
94\end{array}$ & $\begin{array}{r}51 \\
14 I\end{array}$ & $\begin{array}{l}27 \\
73\end{array}$ & $\begin{array}{r}19 \\
227\end{array}$ & $\begin{array}{r}8 \\
92\end{array}$ \\
\hline Totals & . & .. & 272 & & 239 & & 192 & & 246 & \\
\hline
\end{tabular}

ascertained that within this locality the enclosed type of housing was still definitely associated with bronchitis. It should be mentioned here that smoking habits were found not to vary with locality and that they do not affect these conclusions.

This finding seems to confirm the suggestion made earlier that the effect of 'enclosed' housing is to aggravate the effects of atmospheric pollution when it exists.

The importance of cigarette smoking is dealt with in the discussion later.

With regard to the significance of acute bronchitis in early life, the objection can be raised that the individual who suffers from respiratory disease is more likely to recall early bronchial illnesses than the healthy person. Therefore, the figures given in Table 5, significant though they are, must be regarded with that possible criticism in mind.

But it is seen that such early illnesses were found to be twice as frequent amongst chronic bronchitics as amongst healthy controls and the evidence is regarded as strongly suggestive.

Further evidence of infection was obtained by ascertaining the frequency of acute bronchitis at the time of the inquiry. This also showed double the number of bronchitics reporting annual bronchitis as were found amongst the non-bronchitic control group. The evidence of infection is thus strong and we know from the pathologists that it is an essential feature of the disease.

Family bronchitis was a significant finding, but its influence in regard to total prevalence is difficult to assess. No evidence of the existence of the 'bronchitic household' was elicited.

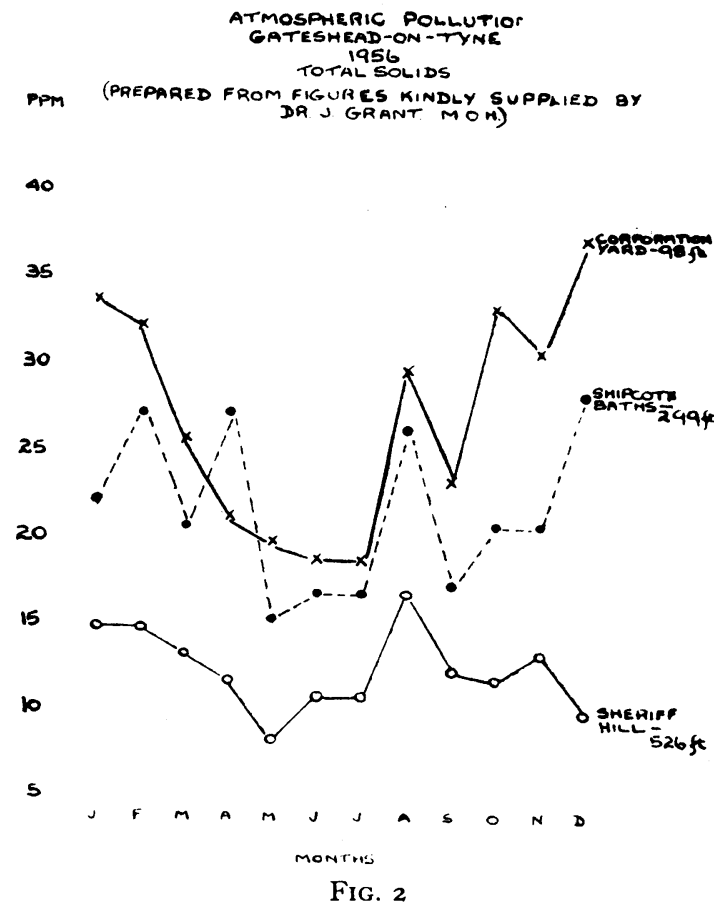

Evidences of allergic illnesses in the family were not significant, but personal allergic manifestations (asthma, rhinitis, eczema and nettle rash) were more than twice as frequent among bronchitics. There is in all this some evidence which suggests that contributional factors play some part in the development of the disease, although it has not proved possible to say how important this part may be. 
Bronchitis (England \& Wales)

spells of certified incapacity-1956

Men. By Regions (related to population at risk)

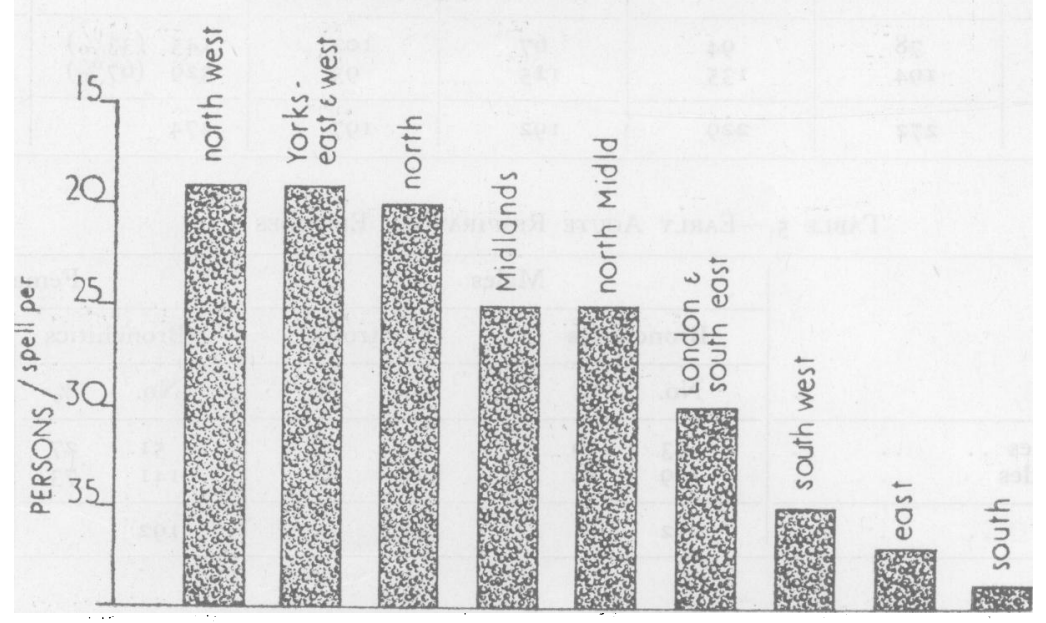

FIG. 3

TABLE 6

\begin{tabular}{|c|c|c|c|c|}
\hline \multirow{2}{*}{ Unemployment } & \multicolumn{2}{|c|}{$\begin{array}{c}\text { Male } \\
\text { Bronchitics }\end{array}$} & \multicolumn{2}{|c|}{$\underset{\text { Controls }}{\text { Male }}$} \\
\hline & No. & $\%$ & No. & $\%$ \\
\hline 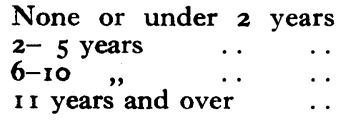 & $\begin{array}{r}181 \\
47 \\
32 \\
12\end{array}$ & $\begin{array}{r}67 \\
17 \\
12 \\
4\end{array}$ & $\begin{array}{r}200 \\
19 \\
12 \\
8\end{array}$ & $\begin{array}{r}84 \\
8 \\
5 \\
3\end{array}$ \\
\hline Totals $\ldots$ & 272 & 100 & 239 & 100 \\
\hline
\end{tabular}

The only evidence regarding a nutritional influence on prevalence which we have was provided by the survey and is given in Table 6 . This shows that prevalence varies with the total duration of unemployment between the wars. It might be thought that this could be related more to social class rather than to unemployment as such, because social classes III and V suffered more than others from unemployment. This, however, is not so and the association is a true one.

There is thus an indication that there is an economic factor which cannot be ignored.

\section{Discussion}

The evidence that even within an industrial city with 9.4 houses per acre an association of bronchitis with atmospheric pollution and with density of housing exists, does seem to offer a possible explanation of the influence of 'urbaniza- tion' noted by Goodman, Lane and Rampling, in relation to mortality.

Constitutional, and possibly hereditary in-o fluences, are significant in a proportion of cases, and an economic association is seen in the relationo to unemployment.

On the evidence regarding mortality, the natural expectation was that general prevalence would follow a similar pattern, being higher in town than in country. Several rural surveys have now been conducted however, which suggest that there is, in fact, very little difference between town and country, in so far as general prevalence is concerned.

In two of these, comparisons with urban surveys by the same authors were possible, and the prevalences were similar. Neither Higgins, nor Stuart-Harris and Hanley referred to their cases as 'chronic bronchitis', but they investigated the frequency of persistent productive cough. This is 'chronic bronchitis' according to the Newcastle definition, which has been given implied recognition by the recommendations of the Ciba Guest Symposium, ${ }^{20}$ which define chronic bronchitis as 'the condition of subjects with chronic or recurrent excessive mucous secretion in the bronchial tree'.

There is thus no evidence that bronchitis is necessarily more frequent in the town than it is in the country. How can we correlate these observations? The most obvious explanation is a variation in severity. If more people die of bronchitis in the town, and yet the disease is 


\section{spells of incapacity from All Causes - 1956 \\ Prepared from M.P.N.I. Digest of Statistics}

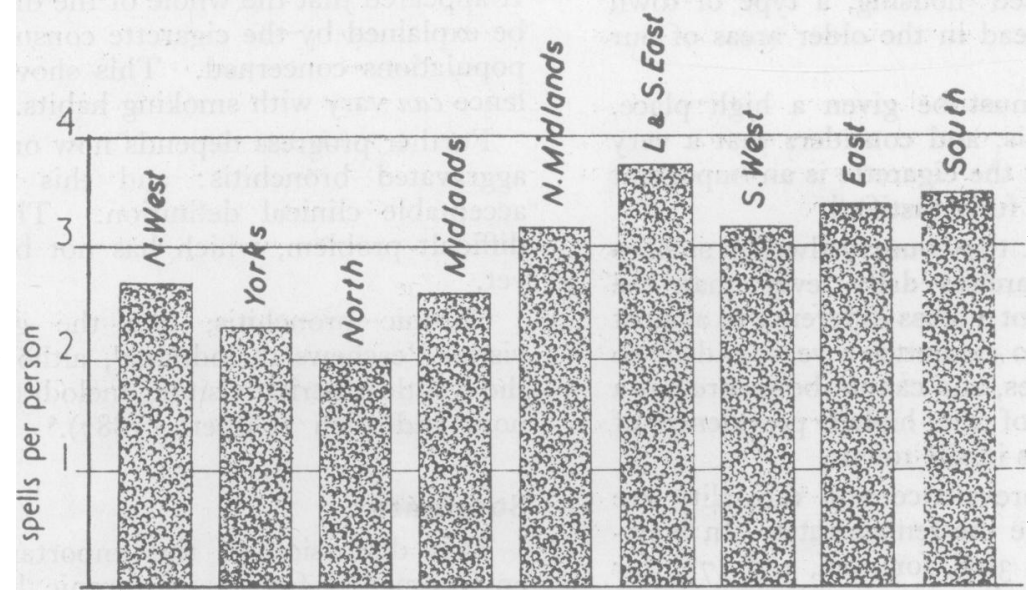

Fig. 4

roughly as prevalent in the country, it is probably more severe in the town-dweller. If this is so, the rate of invalidism in urban districts must be greater, and this is found to be the case.

Fig. 3 illustrates this point. As one passes from left to right, one passes from the highly industrial and urban communities to the rural and residential towns and villages, and the rate of certified sickness from bronchitis falls.

This graph is even more striking when compared with the certified sickness from all causes, analysed by regions in the same way (Fig. 4). The classification by 'spells' is not a very satisfactory one, as the 'spells' naturally vary in duration, but this consideration cannot disturb the general conclusion: namely, that urban conditions are related closely to incapacity due to bronchitis, but not to total incapacity in the insured population.

Further evidence which suggests that urban conditions act by aggravating bronchitis is to be found in the study by Logan and Cushion ${ }^{9}$ of morbidity in general practice. They used various methods to ascertain the calls made on the services of a sample of general practitioners, and the causes.

The most reliable method seemed to be the 'patients' consulting rate. This classified by cause the numbers of patients per 1,000 population who consulted their doctor during the twelve months May, 1955, to April, 1956.

This showed that there was still a definite trend for the predominantly rural regions to have
Bronchit is in General Practice

potients consultıng rates per 1000 population

(by REGION) Loyan e Cushion

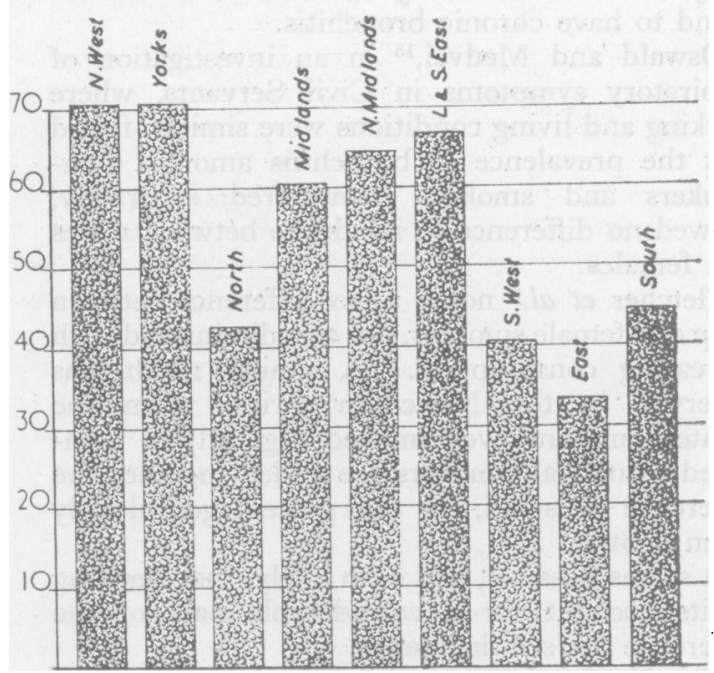

Fic. 5

a lower rate of consultation for bronchitis, although the tougher Northerner complains less.

The rates for the sexes. still show/ male preponderance, but to a less extent than prevalence rates would lead us to expect. 
Our conclusion can only be that bronchitis is more severe, more disabling, and more fatal in the town-dweller than it is in the countryman.

Why is this? One reason, in all probability, is atmospheric pollution, the effect of which is increased by 'enclosed' housing, a type of town planning so widespread in the older areas of our cities.

Smoking habits must be given a high place. Reid $^{17}$ deals with this, and considers that a very strong suspicion that the cigarette is an important aggravating factor is fully justified.

Todd $^{25}$ found that the country dweller smokes on average two cigarettes daily fewer than the townsman. This is not a gross difference ( 9 against 11 ), but it means 730 cigarettes a year, and in 20 years 14,600 cigarettes, and cannot be ignored as a partial explanation of the higher prevalence of aggravated bronchitis in the towns.

The high male prevalence and mortality are almost exactly double the female rates. In Newcastle the figure was $36 \%$ for men, and $17 \%$ for women, aged 30 and over.

The possibility that this difference is largely due to smoking habits is suggested by the fact that in Newcastle $83 \%$ of male bronchitics, and only $4 \mathrm{I} \%$ of female bronchitics were smokers, and that the male addiction was heavier.

If the smokers are considered separately, without consideration of the degree of addiction, $59 \%$ of the men, and $56 \%$ of the women, are found to have chronic bronchitis.

Oswald and Medvei, ${ }^{15}$ in an investigation of respiratory symptoms in Civil Servants, where working and living conditions were similar, found that the prevalence of bronchitis amongst nonsmokers and smokers, considered separately, showed no difference in incidence between males and females.

Fletcher et al. ${ }^{3}$ noted a sex difference between male and female smokers, but this diminished with increasing consumption. A similar result was observed in the Newcastle series, when the greatest amount ever smoked regularly is compared; but if all smokers are added together the difference is small, as the percentages already given show.

It seems possible, and even likely, that smoking habits account for a considerable part of the difference in sex incidence.

The Newcastle non-smokers and pipe smokers have not been compared. Male non-smokers were very few, and pipe smokers were shown by Fletcher et $a l .^{3}$ to be not strictly comparable with non-smokers.

Olsen and Gilson ${ }^{13}$ studied the prevalence of respiratory symptoms and ventilatory capacity in men in Bornholm, which they compared with rural studies in Wales and Scotland. They found a significantly lower prevalence in Bornholm, but noted that in the group of non-smokers $\propto$ there were no differences, clinical or physiological. It appeared that the whole of the difference could $\underset{\sim}{\vec{D}}$ be explained by the cigarette consumption in the populations concerned. This shows that preva- 을 lence can vary with smoking habits.

Further progress depends now on the study of $\frac{\vec{Q}}{2}$ aggravated bronchitis: and this waits for an acceptable clinical definition. This is a most difficult problem, which has not been solved as? yet.

Chronic bronchitis, like the gentle district visitor, 'eschews melodrama', although, also like 8 the gentle district visitor, melodrama breaks in 3 now and then (Gilbert, 1887).4

\section{Summary}

This discussion of the important social and $\stackrel{N}{\rightarrow}$ environmental factors in chronic bronchitis has $ᄋ$ been based on a review of the findings of a survey carried out in Newcastle in 1955-56 (Ogilvie and $\rightarrow$ Newell, 1957), ${ }^{12}$ and amplified by reference to the relevant literature.

It has been noted that mortality and sicknes due to bronchitis both bear a direct relationshif to the degree of urbanization, and are lowest in the countryside.

Pollution of the atmosphere has been considered to be a major aetiological and aggravating $\stackrel{\circ}{\mathbb{D}}$ factor, but it has been emphasized that its effects are much enhanced by the older 'enclosed' type of housing arrangement.

It has been observed that urban life, though it affects the rates for death and for incapacity, does not alter the male preponderance, which is seen also in general prevalence. It is found, however, that the difference is greatly reduced, if smokers 3 and non-smokers are separately analysed. It is considered that cigarette smoking, which has been shown to affect general prevalence, and is thought to cause aggravation, is the chief cause of the excess of bronchitis in the male.

Constitutional influences are significant, although no accurate estimation of their import- $\sigma$ ance is yet possible. Infection, though known to $N$ be an essential feature of established bronchitis, $\underset{\mathrm{N}}{\mathrm{N}}$ is difficult to demonstrate epidemiologically.

The fact that rural prevalence almost equals $\underset{0}{0}$

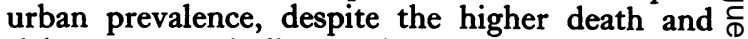
sickness rates, indicates that the town-dweller's $\stackrel{\mathscr{\rho}}{\rightarrow}$ bronchitis is more severe, and underlines the 0 need for clinical criteria of aggravation, so that study of the causes of aggravation can go forward.

\section{,




\section{Acknowledgment}

I must thank Messrs. E. \& S. Livingstone Ltd., of Edinburgh, for permission to publish certain tables and figures from 'Chronic Bronchitis in Newcastle upon Tyne.'

\section{REFERENCES}

I. CRALLEY, L. V. (1942), F. industr. Hyg., 24, 193.

2. DOLL, R., and HILL, A. B. (1956), Brit. med. F., il, 1071.

3. FLETCHER, C. M., ELMES, P. C., FAIRBAIRN, A. S., and WOOD, C. H. (I959), Ibid., il, 257.

4. GILBERT, W. S. (1887), 'Ruddigore,' Act 2.

5. GOODMAN, N., LANE, R. E., and RAMPLING, S. B. (1953), Brit. med. F., ii, 237 .

6. HIGGINS, I. T. T., OLDHAM, P. D., COCHRANE, A. C., and GILSON, J. C. (1956), Ibid., ii, 904 .

7. HIGGINS, I. T. T. (1957), Ibid., ii, 1198.

7a. HIGGINS, I. T. T. (1959), Ibid., 1, 325.

8. LAWTHER, P. J. (1955), Lancet, ii, 745.

9. LOGAN, W. P. D., and CUSHION, A. A. (1958), 'Studies on Population Subjects, No. I4,' H.M.S.O., London.

ro. MAY-see Report-marked in reference.
Ir. MINISTRY OF NATIONAL INSURANCE (1956), 'Digest of Statistics analysing Certificates of Incapacity.

12. OGILVIE, A. G., and NEWELL, D. J. (1957), 'Chronic Bronchitis in Newcastle upon Tyne', Edinburgh: E. \& $\mathrm{S}$. Livingstone Ltd.

13. OLSEN, H. C., and GILSON, J. C. (1960), Brit. med. F., 1, 450.

14. OSWALD-see Report-marked in reference.

15. OSWALD, N., and MEDVEI, V. (1955), Lancet, 11, 843.

16. PEMBERTON, JOHN, and GOLDBERG, C. (1954), Brit. med. $F$., ii, 567 .

17. REID, D. D. (1958), Lancet, i, 1289.

18. REID, LYNNE, MCA. (1954), Ibid., i, 275.

19. REID, LYNNE MCA. (1955), Thorax, 10, 199.

20. Report of the Conclusion of a Ciba Guest Symposium (1959), Ibid., 14, 286.

21. STOCKS, P. (1947), 'General Register Office, Studies on Medical and Population Subjects, No. I,' H.M.S.O., London.

22. STUART-HARRIS, C. H., and HANLEY, T. (1958), 'Chronic Bronchitis, Cor Pulmonae, and Emphysema.

23. STUART-HARRIS, C. H., POWNALL, M., SCOTHORNE, C. M., and FRANKS, Z. (1953), Quart. F. Med., 22, 121 .

24. STUART-HARRIS, C. H. (1954), Brit. F. Tuberc., 48, 169.

25. TODD, G. F. ( (1959), 'Tobacco Manufacturers' Standing Committee, Research Papers, No. I, Statistics of Smoking, and Edition, London.

\section{References continued from page 275-Enquiries into Mental Disorder in Old Age.}

11. HILlbOM, E. (1960), Acta. Psychiat. et Neurol. Scand. Suppl. 142.

1 2. HILLIARD, L. T., and KIRMAN, B. H. (I957), 'Mental Deficiency,' London, J. and A. Churchill.

13. HOPKINS, B., and ROTH, M. (r953), f. Ment. Sci., 99, 451. 14. HUTCHINSON, E. C., and YATES, P. O. (1957), Lancet, i, 2. 15. KAY, D. W. K. (1959), Proc. Roy. Soc. Med. 52, No. 9, 791.

16. KAY, D. W. K., and ROTH, M. (1955), Lancet, ??, $259,740$. 17. KAY, D. W. K., and ROTH, M. (1960), to be published.

18. MALLER, O. (1959), 'Les Particularites Nosologiques de la Schizophrenia. In: Congress Report, II, 63. 2nd International Congress for Psychiatry, Zurich, 1957.

19. MALZBERG, B., and LEE, E. S. (1956), 'Migration and Mental Disease,' New York, Social Science Research Council.

20. MAYER-GROSS, W., SLATER, E., and ROTH, M. (1954), 'Clinical Psychiatry,' London, Cassells.

21. MAYER-GROSS, W., SLATER, E., and ROTH, M. (1960), Ibid.

22. ODEGAARD, O. (1932), Acta. psychiat. et neurol., Suppl. 4. 23. ODEGAARD, O. (1953), Acta. psychiat. scand., Suppl. 80.

24. ODEGAARD, Ö. (1959), 'The Epidemiology of Schizophrenia in Norway, Report of 2nd International Congress for Psychiatry, Vol. III, 49-52, Zurich, 1957.

25. POLLACK, B. (1939), N.Y. St. F. Med., 39, 43 I.

26. REGISTRAR-GENERAL (1954), 'Statistical Review of England and Wales for the year I953. Part I: Tables, Medical,' H.M.S.O., London.
27. REGISTRAR-GENERAL (1956), 'Statistical Review of England and Wales for the year 1955. Part I: Tables, Medical, H.M.S.O., London.

28. ROSE, N. M., and STUB, H.।R. (1956), 'Mental Health and Mental Disorder,' London.

29. ROTH, M. (1955), f. ment. Sci., ror, $28 \mathrm{r}$.

30. ROTH, M., and HOPKINS, B. (1953), Ibid., 99, 439.

31. ROTH, M., and KAY, D. W. K. (1956), Ibid., 102, 14I.

32. ROTH, M., and MORRISSEY, J. D. (r952), Ibid., 99, 439.

33. ROTH, M., OSSELTON, J. W., and GREEN, T. (1960), to be published.

34. SAINSBURY, P. (1955), 'Suicide in London,' Maudsley Monograph No. I, London, Inst. of Psychiat.

35. SJOGREN, T., and LARSSON, T. (1954), Acta. psychiat. et neurol., Scand. Suppl. 89.

36. SLATER, E. (1959), Paper delivered at Maudsley Symposium on Epilepsy, to be published.

37. STENSTEDT, A. (1959), Acta. psychiat. Khb., Suppl. 127. 38. TOWNSEND, P. (r957), 'The Family Life of Old People,' Routledge, London.

39. WALTHER, B. H. (195I), 'Psychiatry of Cerebral Tumours and the Problem of Focal Syndromes and of Psychological Localisation,' Vienna.

40. WORLD HEALTH ORGANIZATION (1959), 'Mental Health Problems of Aging and the Aged.' ('Sixth' Report of the Expert Committee on Mental Health, Technical Report Series, No. 171 .

4I. WEINBERG, W. (1925), in 'Handbook of social hygiene and public health', Vol. I, Berlin. 